\title{
Narrating the War in Postwar Japan: \\ The Interpretation of the Past \& Its Implications for Japan's Relationship with Asia
}

\author{
DONGJU HAM
}

Departmuzt of Hissory: Ewba Woncans Universiby

\begin{abstract}
The dispute oner bistory shou's that there are serious doubts atout Japan's trasition both in and nut of Japan and such doubis work as a critical abrate in defining Japan's intemational role. In this study. I have examined bro postuar Japan's witw of the past was shaped and bow it infuenced lapan's relations with asian nations as a way of explaining the present dispute and its international ramifications. In particular, I boue shoun the basic struture of pastuar Japan's view of the past as it was shaped during the tuo decader after the defeat. Also, despite the apparent successes in numulizing relations with Asian nations. Japun bas failed to fully resnite the intue of the past and its viau of the past plazed a big part in the process.
\end{abstract}

\footnotetext{
This research is sponsored by the granc awarded by the Insutute for International Irade and Cooperation: Ewha Womans Liniversiey in 1997

Direct all correspondence to Dongju Ham, Assistant Profeisior, Bepartment of History, Ewha Womans Liniversity. 11-1 Disehyur-dong, Seculaemun-gu, Seoul, 1201750, Korcal.
} 


\section{INTRODUCIION}

G ntering the 1990s, the notion of a new regional orker in Asia has attracted a great C deal of attention. It is often argued that the end of the Cold War and the breakup of the Soviet Union have reduced the impact of global factors in world politics and increased the weight of regional forces (Katzenstein 1997). In Asia, too, international and national developments are thought to be increasingly shaped by regional dytamics. In particular, the economic integration of Asian countries is considered to be a clear sign of the emergence of regionalism in Asia. However, even those who are opcimistic about the possibility of Asian regionalism concede that the legacy of Japancse imperialistn in Asia is a critical obstacle in the further integration of the Asian region (Katzenstein \& Shiraishi 1997, 367).

Although the history of Japanese imperialism ended more than fifty years ago, the weight of the past is still felt in Japan's relations with Asia. As the textbook controversy erupted in 1982,2 the interpretation of the war ${ }^{3}$ surfaced as a key diplomatic problem for the Japanese government. Since the incident, the Japanese govermment has faced a series of accusations and demands for Japan's atrocities from former colonies and occupied territories

Entering the 1990), the issue also hecame the focus of nationwide debates in Japan as the fiftieth commemoration of the end of the war approached. In particular, between 1994 and 1945, the government's attempt to apologize for Japan's war responsibility in the form of a congressional resolution galvanized nationwide reactions, which revealed the division within the Japanese socicty over the issue. In suro, despite the passage of half a century, menories of the past remain a critical clement in Japan's relations with Asia. This article begins with the simple question of why the dispute over history continues to exert such an influence on Japan's relations with Asian nations.

The dispute over history is a complex phenomenon, requiting analyses from various directions. In this study, I will approach the issue by focusing on the Japanese side. 'To be specific, I will argue that the dispute is closcly connected to postwar Japan's failute in resolving the issue of the past. Japan began to rebuild diplomatic relationships with Asian nations during the 1950s and has successfully accomplished this process by establishing diplomatic relations with Korea in 1965. Considering that the process of re-establishing diplomatic ties with Asian nations required a mutual rapprochement through the resolution of war issues. Japan's successful restoration of its relacionships with Asian nations mighe be interpreted as a sign of diplomatic resolution of the issues between Japan and Asian nations. However, the turning point in the dispute over history was

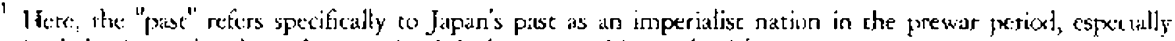
its hehaviors related to the war in Asia berween 1931 and 1945.

2 For a detailed discussion on the develupment of the controversy, sce Allen 5. Whicing, China Eyes Japan, I niversity of California Press, 1989.

"Iis this paper, the war reters to a series of war Japan fought in Asia berween 1931-1945. Fur a disclussion oil the afpellittion of the war, sec Kisaka Junichiro, 1993.

IJapan's relationslup with China was normalized in 19?2. However, North Korea is not yet resolved. Both

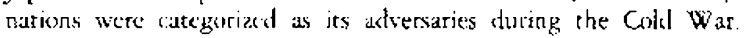


the textbook incident of 1982, which resulted from Japan's at tempt to rewrice and redefine the past. This points to the fact that Japan's sertement of war issues was not sufficient. In this study, I will argue that the problems in postwar Japan's relations with Asian nations bave been closely connected with its viex of the past. In particular, I will show that a significant number in Japanese society have remembered and narrated the prewar history in ways chat have betn vety different and, sometimes, contradictory to Asian neighbors and the remaining Japanzese population. They have refused to accers the view of prewar Japan as an evil invader. In their refusal to repudiate prewar history lies the close connection between history and nationalism. In che late nineteenth century, the creation of national memories of the Japancse people played a central role in providing a national identity to modem Japan as a nation-statc. As Japan took the route of imperialistic development, historical reckoning became intercwined with Japanese imperialism, thereby developing a narrative of imperial Japan around the notion of the eternal Japancse imperial rule. In the end, the memories of the national past were jocxtrically intertwined with Japan's nationalism and the memory of Japancse imperialism was not an exception. However, what's more importan is the fact that their view of the past played a significant role in shaping the siews and policies of the Japanese government in dealing with the settlement of diplomatic issues with Asian nations. Furthermore, I will show that the basic scructure of Japans view of the past and irs impact on pessewar Japan's relationship was shaped during the first two decardes after the defcat. In other words, 1 will argue that the developmente of Japan's position during that period laid the ground for the present dispute and without changes in that structure, the dispute would not be resolyed in the near future. Thus, in orders to do that, I will narrow the focus on the period hetween Japan's deceat in 1) 45 and the normalization of relationship with Korea in 1965 , during which the basic strecture of posewar Japan's relationship was determined.

\section{POSTWAR JAPAN'S NARRATIVES OF THE WAR}

At noon. August 15, 1945, Japan's emperor had bruadcasted the announcement of surtender, ending a series of war that had begun in 1931 in Manchuria. The date marked the beginning of the postwar period in Japan. The surrender was epoch-making in many ways. Japan lost its identicy as an imperialist nation as it lost all the foreign territories. It lost its independence, as it was put under the Allied occupation. In addition, various aspects of sociery were retormed as the occupation authorities attempted to transform Japan into a democratic society. In short, "postwar" Japan is marked with discontinuity or historical scverance (Gluck 1992, 3-4).

Amung the changes following the defeat was the change in Japan's narratives of the war. During the war, Japanese called the war, "the Greater East $\Lambda$ sian War," which argued that Japan's wat efforts were to liberate the Asians from Westem imperialistn. However, by the end of 19.15, the war came to be called, "the Pacific War," which dermunced Japans actions in the war as aggressive. Despite such a change in view point, it is wrong to assume that Japan's narratives of the war underwent a complete turnabour 
on August 15, 1945. On the contrary, support for the narrarive of the Greater East Astan War or, at least, sbjections to the narrative of the Pacific War, remained strong in postwar Japan.

\section{The Defeat and the Narratives of the W'ar}

During the 1930 s and the early 1940s, Japan was in a state of constant war. With the excupation of Manchuria is 1931 in the beginning, the fapanese military invarled China. By the end of 19:1, the war had expanded to Southeast Asia and the Pacific, as Japan entered the war with America. The war ended on August 14, 1945 as the Japanese government surrendered to the Altied Powers. On September 2, the wat officially' ended is Cieneral limezu, the Chief of Stafts of the Army, and General MacArthur: the Supreme Commander of the Allied Powers in the Pacific (SCAP), signed the instrument of surrender on buard the battlestip Missouri. Since then, Japan was put under the Allicel occupation until the San Francisco Peace Treaty went into effect in 1952.

The defeat initiated a new phase in Japan's development. Most importantly, the defeat led to the end of the hegemony of Japanese imperialism in Asia. Following the terms of the Potsclam Declaration, Japan lost its colonial empire and was put under the Allied occuparion. Also, the defeat marked a turning point in Japanese history, as the occupacion authorities led by General MateArthur aimed at descroying all remnants of Japanese militarism and transtorming Japan inco a democracic society. In onder to achieve this goal, it intreduced far-reaching reform policies to the Japarese society. During the postwar reform, thus, prewar Japan's institutions and ideologies were blamed for the calamities and discredited. Instead, new institutions and concepts were introduced and adopted.

\section{The Deteat and the Japanese Government's View of the War}

The process of deconstructing prewar Japan included the radical transformation in the way Japan's prast was conceved and marrated. As it is known, prewar Japan's official cerm for the war was the Greater East Asian War. The raison ditri behind this name was to liberate Asians from the Western imperialism and to construct a sphere of co-prosperity for Asians. Thus, the name, the "Greater East Asian War" embodied the ideology of Japanese expansionism in Asia." While the Japanese government propagated the war as a seruggle for Asians against Western imperialism, the Allicd l'owers defined the war as a conflic berween democracy and militarism and complosized the illegitimany of Japan's actions in the war. Thus, the Potsdam Declaration depicted the Japanese government as having "irresponsible militarism."t In this sense, Japan's deteat in the wat was tantamounc to the victory of the view of the Allied Powers. Consequently, the replacement of the narrative of the Greater East Asian War with the view of the

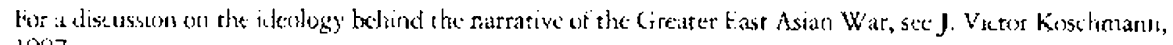
1907 ?

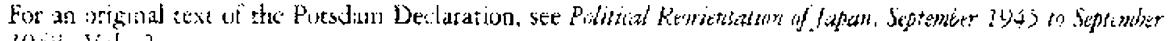
30)ix. Vol. ?.
} 
Allied Powers trocame inevitable.

However, the defeat itself did not change the way the Japanese viewed the war. The Japanese government still maintained that the war was the Greater East Asian War, which fought for the liberation of Asia from Western imperialism. The fact that Japan's surrender did not change the Japanese government's position is found in the imperial rescript ending the war. Japan's surrender became publis with the announcennent of the imperial rescript, which accepted the Potsdam Declaration. Whilc accepting the Potsdan Declaration, it maintained that Japin had fought a just war. It stated that Japan's goal in the war had been to keep the self-existence of the empire and the peace in East Asia, not to proscribe other's sovereignty and to invade their territories. By contrast, it denounced the Allied Powers for using atomic bombs. It argued that Japan's deciston was not only to avoid the ruin of the Japanese nation, but also the destruccion of the civilization of mankind. Furthermore, it concluded by expressing azologics to the nations in Asia which, it clainzed, had cooperated with the empire for the libcration of East Asia throughout the war, and to the Japancse who had died or lost beloved ones in batcles. In short, the rescript maintained the legitimacy of Japan's position in the war (Gaimusho 1965, 636-37).

On August 17, the Higashikuni government was formed to deal with the issues following the defeat, being the first postwar cabinet, the Higashikuni government was faced with the issue of explaiting the causes of the deteat and the issuc of wat responsibility. In the press conference for Japanese reporters held on August 28, the new Prime Minister argued that the deteat was due to the loss of war capability, the dropping of atomic bombs, the entry of the Sovict Inion in the war, and the excessive wartime control of the bureaurats. White recognizing partial responsibility of the government, shown in his statement, "the policics of the government were not good," he argued that the decay in poople's morality (kokumin no) sutarea mma) was another cause (Yoshida 1995, 26). In other words, his approach to the issue of war responsibility denied from the viewpoint of having been defeated, not of the wat itself. $A$ s for the nature of the war, there was no recognition for Japan's wrongdrings. In the next press conference held for foreign reporters on September 20, the Prime Minister faced incjuiries about the war responsibilities of the emperor. He answered the question by saying. "the war was put inso action in a secret manner by the hands of a few members of the army and the navy," and strongly denied the responsibility of the emperor ( $\Lambda$ waya 1980,334 ). Alchough he recognized the responsibilities of the kcy trilitary leaders, the focus was not on clarifying their tesponsibilities but on avoiding the war responsibility of the emperor. In shore, the statements were made not to repudiate the narrative of the Greater East Asian War, but to defend the Japanese government and the emperor.

In October 1945, the Shidehara cabinet replaced the Higashikuni cabinet. The new Prime Minister was a moderate diplomat and known for his conflicting views with militarists in the 1930s. However, he was not much different from his predecessors in his view of the war. The Shidetara cabinct's position regarding the war is found in a document entitled, "The Issue on War Responsibility," which was passed by the cabinet on November 5, 1945. Two points about the bill need to be noted. First, it called the war the Greater 
East Asian War and maintancd that the war had broken out due to the inevitable circumstances surrounding Japin. Because Japan was under milicary and economic pressures, it argued that the declaration of the war was nothing more than an act of self-defense. Secondly, it strongly denied the war responsibility of the emperor. It argued that the emperor had done nothing but followed the decisions made by the military and the govertment. Instead, it depicted the cmpcror as the defender of peace (Awaya 1980, 341-42). In short, the Shidehara grovernment did not view the war as a war of aggression. Nist only did it use the name of the Greater East Asian War, but it also cmbraced the nation of the war as an act of unavoidable resistance againsr Western pressures.

In sum, Japan's acceptance of the Potsdam Declaration did not mean anything more than the recognition of Japan's deteat to America. The Japanese government did not accept the view of Japan's war as an act of "irresponsible militarism." In line with that, is position regarding wat responsibility was only limited to searching for the causes of the defear.

\section{SCAP and the Construction of the Narrative of the Pacific War}

As with other areas of the postwar reform, the occupation authority played a central role in the reconstruction of the narrative of the war. Before SCAP intervened in the narrative of the war, the war was still called the Greater East Asian War. The Japanese government continued to defend Japan's position in the war and miny Japancse shared the same view. It was the initiatives from SCAP that served as the initial push for the construction of new war nasratives.

The view of war by the occupation authorities was based on the Potsdam Declaration. The declaration, which was issued on July 26, 1945, defined the rar between the Allied Powers and the Triple Alliance and as a struggle between democracy and militarism. It depiced the Japanese governonene as having "irresponsible militarism" and demanded "the climination of powet, anthority and influence of those who have led the Japanest into the path of world conquest." When the occupration athorities began to build their own narrative of the war, it was this notion of Japanese militarism that served as their basis.

Suprence Commander of the Allied Powers in the Pacific (SCAP)'s first move toward building a new narrative was made in December 1945, when it forced major newspapers

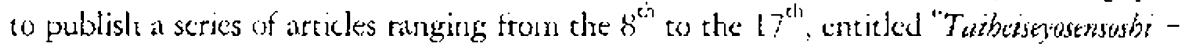

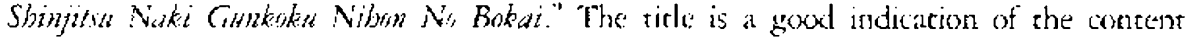
of the article. For example, the war was called the Parific War (Tatheivanara), which replaced the Greater East Asian War as the official name of the war. It tefined prewar Japan as a militarist country (junkekzi), implying that its collapse was a natural outcome of its unfaithtulness. Also, the introduction made clear that it was written in order to highlight the crimes of Japanese militarism. According to Yui Masatomi, the view of the war cars be summarized as follows. First, the Manchurian Incident of 1931 was viewed as the beginning of the war. Therefore. Japan's wat was regated as having been continued from 1931 to 19.45 without pausc. Second. it assigned the responsibility 
of the war to the militarists of the military and contrasted them from the emparor, the court group, and the conservatives in the business. Third, it depicted and denounced the cruelties of the Japanese army, such as the Nanjing Massacre, in decail. Fourth, in regard to the fights before 1941, the main emphasis was on the diplomatic activicies of the United States while disregarding China's etforts. In sum, its emphasis was not on the entire period of the war from 11)31, but on the phase of the American-Japanese War foughte over the Pacific (Yui 19)'1, 3).

SCAP's proposal of the narrative of the Pacific War was accompanied by the prohibirion of the name, the "Greater East Asian War" from public usage. On December 15, SCAP issued a directive on the dissulution of religion of the Srate (kakka shinto wi kantzm shitei), which ordered the separation of shincoism from the state. In addition, it prohibited the use of phrases with connotations of state strintoism, milisarism, and ultra-nationalism in official docuenerts. Anong them was the mame the Greater East Assan War." As a result, by the end of 1945, the Pacific War cane to replace the Greater East Asian War as the name of the war (Yui 1994, $j-4$ ).

However. the impact of SCAP's attempt to discredit the prewar narrative of the war was limited in scope and nature. Most of all, as the name, "the Pacific War" indicates, SCAP's attention was focused on the war between America and Japan. Jn contrast, Japan's aggression azatins $A$ sia did not attract much attention. The neglet of Asia in the nartarive of the Pacific War was reflected in the process of the Tokyo Trial. One of the criticisms of the rrial was over the anbalanced treatment of Japan's war crimes in Asia. Although Japan's aggression in China (since the Manchurian lncident) was included in the list of crimes, it was the war with America that was the focus of the trial. ${ }^{8}$ Consequently, those who advocated the war against America were punished, while those who opposed the wat with America were not tried at all (Waktaty). Furthemore, the development of the Cold War, as well as the Ancrical's preoccupation with the Communises, worked to end the trial presuaturely. Thus, after anueuncing the sentences of twenty-five criminals in November 19. 亻 releaser?

In short, the construction of the narrative of the Pacific Wat was an important step in averconing the prewar view by officially repudiating prewar Japanese militarism. At the sanle time, however, it contained significant limitations in perspective; opening the dour te challenges malale by the coriservative camp in Japan soon after the independence.

\section{The Impace of the Narrative on the Pacific War}

The establishment of the nartative on the Pacific War marked a turning point in the Japanese view of the past. The publication of the articles in newspapers informed the: public of the atrocities of the Japanese military in Asia. Also, as the Tokyo 'Irial proceded, somc unknown facts about Japan's atcocitics in Asia became public. Therefore,

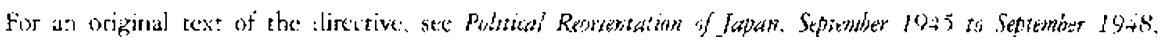
Visl. 2.

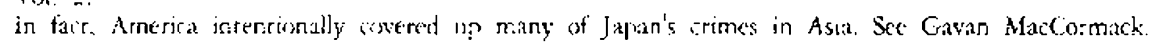


it is possible to say that the narrative of the Pacific War laid the ground for a critical re-examination of the war in the Japan. In particular, Marxist scholarship in postwar Japan adopted it as the basis of its view. They rejected prenat Japan's history, as they considered it to be militaristic and aggressive, and adopted the narrative of the Pacific War instead. It is not to say that these scholars embraced the narrative without modification. There wete significant differenes between American and Marxist inrellectuals. Japanese intellecruals found the causes of the war in the socio political structure of prewar Japan, while Americans tended to blame the scheme of militarists and their collaborators (Yui 1994, k1). Consequently, they tended to reject the war in its entirety. In general, however, Japanese scholars did not pay much attention to the war itsclf. When describing the war, their main interest was in economic structures and political instirutions, especially in the emperor system (Yui 1994, 9). It was only in 1953 that they produced the first full-scale work on the wat entitled, the Kabbijo Sensosi. Published in five volumes. it attempeed to place the wars between 1931 to 194.5 within the moventents of world history and grasp the meaning by combining various elements of the military, politics, society, economy, and culture in an unified way (Nagahara Keiji 1977, 17-18). The lack of interest in sarrating the war can be attributed to the fact that their main concems were to accomplish postwar democracy and to view Japan's history in terms of the laws and stages of historical development." In short although Japan's progressive intellectuals scjected the prewar narrative of imperial history and airned at the consuruction of a new historical marrative, they did not pay full attention to the explanation of the war.

In the meantime, the Japanese government under Allied occupation was forced to adopt the narracive of the Pacific War, thus recognizing the view that Japan was the aggressor in the war. However, it did not mean that the Japanese government whole-heartedly accepted its responsibility in the war. Its basic position coward the issue of war responsibility was to evacte and minimize the issue, which is well-tevealed in the San Francisco Peace Treaty. Because the treaty meant final resolution of the war between Japan and the Allied Powers, the issue of war responsibility was a central issue when signing the creaty. The issue was mentioned in the eleventh and fourteenth article of the treaty. (1)

It is true that the treaty was significant in the sense that it marked the first official rccognition of Japan's war responsibility. However, the way Japan recognized its responsibility was very limited. Japan avoided mentioning the issue of war responsibility in a direct manner by stating that it would accept the result of the Tokyo 'Trial. Also, it restricted its responsibility to the Allied Powers and did not mention the responsibilities toward Asian nations. Most of all, what the clauses meant was that Japan would neither openly

"For instance, the themes of the armual meetings of the "Rekkers" in 19.19 and 1950 were "l3asic. Laves

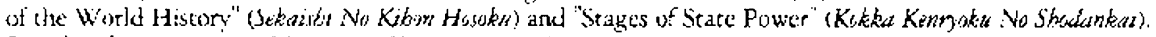
See the discusslisns un Nayahara Keiji, pps. 5-13.

"Aricle II reads that Japan acceprs the judgemenes of the Suernatuonal Military Tribunas for Far East

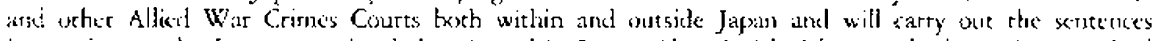
impased upun rke finganese sarionals imprisoned in Japar. Also, Article if (ai reacts that it is recognized

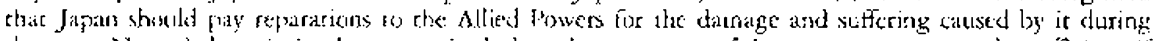
the war. Novertheless, it is also recognized that the resources of lapan are not presently suificiont if

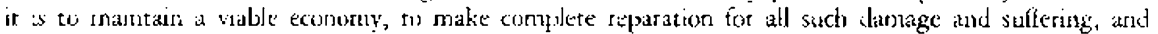

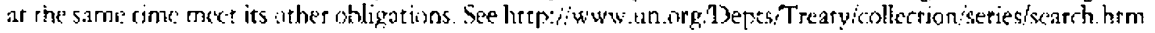


challenge nor cagerly suppors the ratrative of the Pacific War. Since then, the Japanese government maintained the principle of avoiding any mention of its war tesponsibilities. It was only in the Sino-Japanese Communique of 1972 that it broke the rule and officially apologized for its wrong doings during the war.

\section{Independente and the Changes in the Narratives of the War}

The Allied occupation of Japan of ficially ended in April, 1952. The advance of Commurasm in East Asia, particularly the ourbreak of the Korcan War, forced America to consider a peace treaty as a way of ensuring Japan's strategic partnership with the U.S. in the Cold War. Thus, following the negotiations, peace treaty was signed in September 1951 and went into effect in April 1252. As a result, Japan regained independence. The independence marked a turning point in Japan's developnent as it freed Japan from foregen cuntrol. Most of all, Japan gained the freedom to decide its own policies without overt intervention from the Ametican government.

The newly indepenklent Japan was a nation very different from what it used to be teforte the defeat. During the postwar reform, Japan underwent far-reaching shanges. However, by the time Japan rgained its independence, the postwar reform had already taken the so-called. "reverse course," which refers to the trend to revise and reverse the democratic reforms during the early stage of the occupation. 11 The independence was to further accelerate the "reverse course." it is clear that the "reverse course" during the lacer seage of the ckcupation did noe amoust to the rotal reversal of the outcones of postwar reform. Still, it is also clear that the policies of the "reverse course" strengthened conservative voices in Japan. "' Before being ousted from the post in December 1954 by the members of his own Liberal Party, Yostida took measures intended to reverse or diminish the reforms in the late $1940 \mathrm{~s} .{ }^{13}$ lo line with it, the views opposite to the rarrative of the Pacific War began to be voiced with increasing gusto.

\section{The Conservacive Government and lts View of the Past}

The predominance of conservacives in the government is one of the most distinctive characteristics of Japancse politics in the postwar period. With the Katayama cabinet

1: The American governmenis policy zuxidrd Japan began to change in 194 ? as the rivalry with the Soviet Emun became clear in Earope. In addition, the rise or Connmusisen in China forced the American guverament to seview its strategy in Fast Asia. As the military and strategic confrontation with the Communist camp became the firse privrity. SCAP's god in Jajan changed from the eradication of Japanese milirarism to :he consolidation of Japan's stratchic role in the Cold W'at, As SCAP took the "reverse course," a considerable portiun ot the postwar reform was either aodified or abandoned. See Asai Yoshio.

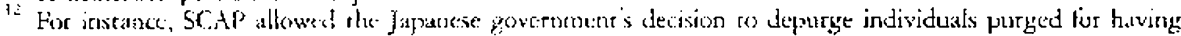
been exponenes ne agents of militarism, aggression, and militane narionalism. The depurge aras proceded

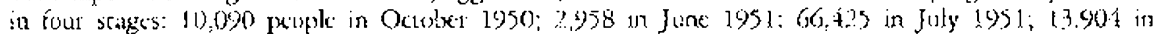
August 1951. Cansequenty, former army and nav officers and high government officials and leaders of businiess and industry, have been vusted from public life.

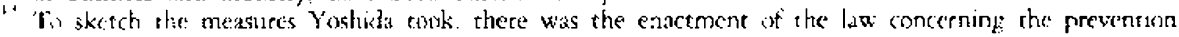
of subve:sive activitics, the centralization of the police, and the re-establishment of the military furce. Sce: Mikini) Halle: pro. $: 56.58$. 
(1947-48) as the sole exception, postwar Jajan's governments have been dominated by conservatives. Furthermore, after the merger of the Democratic and Liberal Parties into the Liberal Democratic Party in 1955, Japanese politics came to be characterized by one-party dominance.

It is difficult to define the ideology of conservative politicians in one word. However, it is possible to characterize their attitude toward the past as positive, ine of the dues to their views of che past is their persunat backgrounds. Many of them played active rules as politicians and burcaucracs during the war. For instance, Yoshida Shigeru, who first led the cabinet of the Liberal Party hetween 1946 and 1947, had formed the second cabinet in ()tober 1948 until December 1954, and was a former diplomat. in Manchuria. Kishi Nobusuke, the Prime Minister from 195: to 1\%60, was active in Manchuria in the 1930s as a reformist bureatucrat and the Minister of Commerce and Indusey in the Tojo cabince. He spent over three years in prison as at war crime suspect until his release at the end of 1948, when the Tokyo Trial was suspended.

One s'ay to understand the conservative govemment's view of the past is through their efforts co defenc Japan's national identity. From the beginning, the Japanese governmen was intent on relying on nationalism as a backbone of the newly independent Japan. By doing so, it retied on the symbols and sensibility of prew ir nationalism in constructing postwar Japan's national identicy and, consequently, was criticized as attempting to revive the "reminiscence of the glory of the Japanese empire" (Inoue Kiyoshi 1959, 8).

One of the clues on huw the conservarise government envisioned a new national identicy can be tound in its attempe to reinstate the National Foundation Day (Kigensotsi). 1952 , the government first submitced a bill to restore is as a national holiday. First instared in 1872, it was based on the day of Jimmu Tenno's enthronement as recorded in Vibari Shoki and was one of the two most important national holidays in prewat Japan. ${ }^{15}$ By assuning the begiming of the imperial house in the record regarding finmu Tenno in Nimn Sbrtki, the celetsration played an important role in instilling the beliet is the perpetizlity of the imperial housc and the Japanese nation. Consecpuenty, it was only natural that the occuparion authoricics abolished it in 1948 . However, with the signing of the peace treaty, the Japanese government revealed the intention of reviving it as an otficial holiday and attempted to submit a bill. Although its attempt was thwarted due to the opposition by the progressive forces, it contirued to push it forward and, finally, succected in enacting it into a law in 1966 (Toyana and lenaga).

Another indication of the government's pexition was found in the area of history aduation. Education was one of the rnost inportant areas in postwar reform. The occupation authorities belicved that prewar Japan's education had been one of the primary causes of Japanese militarism. As pare of the effor, SCAP set up the social studies course in April 1947 in place of former courses on echics, history, and geography courses. However, soon after the independence. the government attempted to reverse the education retorm. The 
governmenc's gorals consisted of two clements: the emphasis on patriotism and loyalty to the nation and the controt of the contents of education. Already in 1953, Asahi Shimbsn reported that Ikeda Hayato, Prime Minister Yoshida's delegate to America, and his American counterpart agreed in a meeting that the Japanese government would be held responsible for the encouragement of the environment to enhance patriotism and voluntary spirits for self-defense through coducation and publicity. Also, the government west chrough scveral revisions of Essentials in Teabing Guidelines (Gokusbu Sbito Yorjo). According ro the guideline revised in 1956, the goal of history educarion was defined "to elevate the realization of the Japanesc and, at the same trine, to collance affections roward the nation (minzoku)" (lenaga Saburo; "Foyama Shigcki). Soon, the government hegan to improse the goal on the content of textbooks, which is noted in the Ienaga Trial. The legal battle between lenaga Saburo and the Ministry of Education began when his history textbook (Shin Nitwrabi) tailed to pass the textbook aturhorization test in 1962 for including frictures highlighting the dark sicke of the war. When lenaga reapplied for the test atter some revisions in 1963, the ministry demanded that scveral additional changes be made. For instance, it demanded him to eliminate the description of the: Pacific War as "reckless," by changing the place of the pictures of emperor and empress from the bottom of the page to the very rop, and by calling U.S. military base "facilitics." In the end, lenaya filed for a trial arguing for the illegality of governmene demands in 1965 . Still, the authorized history textbooks came to assume the following characceristics: deleriun of war experiences; discourse on the status of the emperor; clevacion of incerndtional stacus; and emphasis on culture (Yokoyama 112). In shore, the government pulicy on history textborks was ro construct an enperor-centric history, while de-emphasiaing the: negrave denents of history such as the was experiences.

The goverument's pusition over the past was more clearly revealed in its policy on the release of war criminals. As mentioned earlier, the Japanese government officially accepted the result of the Tokvo Trial in the peace treaty. However, as soon as the peace treacy went into effect, calls for the release of war criminats were voiced." As for those movements, parties responded by adopting resolutions demanding the release of war criminals. In the end, the last remaining A-level wat criminal was released from the Suganx Prison in 1956 (Sato Takeo 83.81). Then, what was the view of the war in thost: resolutions? For instance, the resolution decided in the Ifouse of Representatives on August 3, 1953 argued that the full amnesty of those who have been convicted for war crimes was an earnest wish of the people, and being unable to achieve that was enorionally unbearable for them (Yushida 1995, 84). What is striking in the argument was that it regarded the conviced criminals not as someone who had inflicted great harm onto orhers, but as someone who had endured sufferings. In short; it is possible to characterize the atricude of the conservative government toward the past as synpathecic.

\footnotetext{
1: On the issuts and pregress of the erial, ste vamimoen Katsucushi

1. For instincte over 18,000 people participated in a congregation held on Noversber 11 , igs.5 lot the rlleilst of war cromimals. See Yoshima, p. 8 ?
} 


\section{Popular Consciousness and the Affirmation of the War}

The Japanese government's view of the war was not an isolated one. Instead, it was shared by a significant number of people in the Japanese society. By the end of 1945 , the official name of the war in Japanese society changed from the Greater East Asian War to the Pacific War. With the change in name, the official evaluation of the war also shifted from posicive to negative. The establishment of the narracive of the Pacific War, however, did not result from fundamental changes in popular consciousness. Despitc the defeat, the ideological claim of the war as the Greater East Asian War survived in popular consciousness. By contrast, the issue of war responsibility did not gain much attention and remained a marginal issue. It is true that consciousness about war responsibility has shown progress in the late 1950s (Ishida 1995). Takeuchi Yoshimi's discussion of Japan's responsibility toward Asia (parcicularly (hina) should be noted. At the same cime, however, the popular mood in Japanese socicry was increasingly shaped by those who rook opposite positions.

Challenges to the narrative of the Pacific War began to appcar about the time of the peace creaty. One of the first indications was the publication of war experiences wricten by former milicary members (senkemino). According to a survey, only thirty-six of such books werc published between 1945 and 1949. However, that number suddenty increased from 1950. For instance, there were twenty-five volumes in 1950, twenty in 1951, thirty-two in 1952, and forty in 1953 (Yoshida 1995, 85). The popularity of war memoirs indicates that those who had experienced the war became much more assertive about their memories that had been suppressed under the occuparion. However, more important than the number of books were their views of the war. It is impossible w generalize the views of the war in thuse books. However, it is possible to examine what che basic vicwposints of the military members were like by looking into Daitok Sensi 7enshi (DSZ). fitst published in 1956.18 While other such books were individual works, this book was a result of collaboration by former staft memlers who had been in charge of the strategies in each milicary operarion. As the preface made clear, this buok rccorded the development of the war by focusing on the strategies of Japar's government and military in each operation. 1 ?

'Ihen, what was their historical narrative like? The first indicator of their historical martative is the ticle. This work wficially used the designation of the war as the Greater East Asian War, which had disappeared from the public duc to the prohibition of the occupation force. Simply adopting the title suggested a challenge to the narrative of the Pacific War. Also, the war was narrated in a way that supported the narrative of the Greater East Asian War. For example, when describing the causes of the war. it blamed England for searching for colonies throughout the world and expropriating people who were weak and backward in civilization. By contrast, it justified Japan's

is According to Yeshida Yutakia, this buok showased the cypical way uf thought of the scatf members. Sic Yoshida, 1. 87

(4) Aording to irs jreince, this work was based on the atficial recorcis of the government, the military and secret operation journals, the oral statements and writings of former militars menters and sother relared individuals. See Diatioe temen 7.andit, p. A 
position, saying, "because of narrow lands, material shortages, and growing population, Japan had no other option but to bind irself with the Asian continent, which was the only means of survival" (DSZ, 2-3). Thus, the second Konoe cabinet's decision to occupy the northern part of Indochina was viewed as an act to "gain the materials of the South, to break free from the economic dependency on England and America, and to consolidate the preparation for self-sufficiency" (DSZ, 22). In short, it adopred the narrative of the Greater East Asian War in explaining the causes of the war, thereby defending Japan's position in the war.20

The historical narrative of this book was closely related to the nationalism of the former members of the Japanesc military. 21 In fact, it is not an overstatement to say that the boots was a product of the restoration of conservarive nationalism. In evaluating the occupation period, for instance, the author lamented that a great number of Japanese were devocing themsetves not to the reconstrustion of the fatherland, but to self-consolation by placing responsibilities on others and blaming one another. Moreover, he argued that they artempted to justify the present by denying anything that was traditional, resulring in spiritual panic and ideological confusion. As a result, he deplored that the Japanese lost their confidence and pride in their own nation and people (DSZ, 1018).

While the narrative of Daitox Senso Zenshi was an indirese challenge to the narrative of the Pacific War, Hayashi Fusao's Daitoa Senst Koteiron (DSK) and Zoku Daitoa Seno Koteinn (ZDSK) were much more disect. Hayashi's view first appeared in Cbur Korm between September 1963 and June 1965, and was later published as two-volume books.

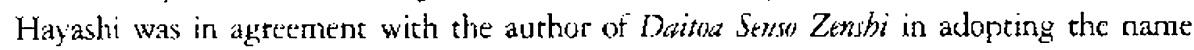
of the Greater East Asian War. However, he dit not stop at using she name. As the titles of the books reveal, Hayashi challenged the narrative of the Pacific War in an open and durec way by affirming Japan's position in the war.

He began the book by declaring that the time had come for the Japanese to scexamine the Greater Eist Asian Wat through their swn eyes (DSK, 11). What he implied was that the war had been viewed from the vierwpoint of Americans. In Facr, he criticized the postwar years, saying that Japan during that period had been in a state of demensia due to the defeat (ZDSK, chapter 19). He argued that the Greater East Asian War was the last stage of East Asia's Hundred Years War, in which Japan had fought against Western invasions for the god of cmancipating Asia from Western domination. Consecuently, Jajan was not the invaker but the defender of Asia. As Japan ended in defeat: Asia came to be dominated by America and the Soviet Linion (DSK, 23). Here, Hayashi presented a view of prewar Japan that was radically different from that in the narrative of the Pacific War. He depicted Japan as the defender of Asia from the invading Westerners. Thus, the war took on a quite different meaning. According to him, Japan was the defender of Asia, while Amcrica was the aggressor. Furthennore, his argument was presented in a way that appealed to the narionalistic sensibilicies of ordinary prople. For example, he was appealing to the national pride of the people,

In relation to this, Yoshida evaluated it as "a baxk lor the self-defense of chose who wete responsible fir the war." p. 5 .

21 The wrotongs of tomier saaff members were published mosty in the tarly 1950 s when the peace creaty

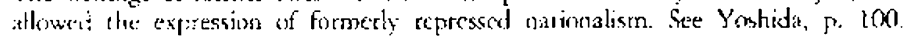


saying, "some twenty years after the defeat have gone by like a bad dream. As a result, Jupan achieved renaissance like a dream." Also, he appealed to the emotional wounds of the deteated people, saying, "I detest those who are calling the war a war of reckless crime and the deaths in the war useless. They are not only stupid but also sordid liars" (ZDSK, 367).

The influence of Hayashi's view in Japanese socicty was limited (Yoshida 1995, 128). Hayash'ts argument net strong reactions from both the conservatives and the progressives. His open advocacy of the war was apprehended as a signal of revival of militarism by many of his contemporaries. Nonetheless, it is also true that his view was not an isolated one. His argument survived the torrent of criticisms and served as a prototype for the numetous books published thereafer.

\section{THE ISSLE OF THE PAST AND JAPAN'S RELATIONSHIP WITH ASIA}

One of the consequences of Japan's defear was the collapse of Japanese hegemony in Asia. With that, Japan's official relationship with Asia was also cut off. It was after the signing of the peace treaty that Japan began to normalize its relations with Asian nations. The contral issue in Japan's negotiations with Asia was the issue of the jast. As for Asian nations, the bitet mernories of Japanese dominance worked as the most imporrant obstacle in the rehabilitation of official relationships. Consequently, rhe sectlenent of the issue of the past occupied a central place in Japan's relationships with Asia.

The basis of postwar Japan's approach to the issue of restoring official relationships with Asia was provided by the San Francisco Peace Ireary, in which Jasan recognized its war responsibilities. In linc with that, the issue of war reparations emerged as the main focus in the negotiations for the re-establishment of official diplomatic relationships. However, Japan's settlement of war issues was proceeded with many problems. In particular, throughout the negniations, the gap herween Jajan and its counterparts in assessing and dealing with the past became evident. Japan's position throughout the negoriations was characterized by two elements: avoiding the explicit nentions of Japan's wat responsibilities and minimizing the amounc of war reparations.

\section{The Occupation Period (1945-1952)}

Japan's relationship with Asia was on icc during the occupation. The abscnce of Japaris official relationship with Asia during this period contained two facets. On the one hand, Japan lost sovereignty to the Allied Powers. Consequently, Japan was not in a position to pursue the normalization of relations with Asia. On the other hand, the issue of the past, particularly of the war, cmerged as a main problem in restoring the relationship with Asta, delaying Japaris reintegration into Asia.

During the occupation, Japats's sovereignty was in the hands of the occupacion authorities, which meant that it was the American government, not the Japanese government, that took control of Japan's fortign relations. Conseguently, America's vien of prewar Japan 
and its war played a decisive role in shaping Japan's relations with Asia.

America's view of the war influenced Japan's relations with Asia in two ways. First of all, it was directly related to the disintegration of the Japanese empire. As mentioned earlier, America viewed prewar Japan as being dominated by militarists and repudiated its aggression into Asia. Thus, during the sar, it made it clear that Japan should be deprived of all its foreign territories. The Porsdam Declaration demanded that "the terms of the Cairo Declaration shall be carried out and Japanese sovereignty shall be limited to the islands of Honshu, Hokkaicko, Kyushu, Shikokı, and such minor islands as we determine,":2 Consequenty, when the Japanese government accepred the terms of the Potsdam Declaration and surrendered to the Allied Porers, the disintegration of the empire became a matter of fact. With the surrender, Japan had to give up newly occupied territories in China and Southeast Asia, but also colonies such as Korea and Taiwan. Also, following the defeat, Japanese nationals living in Asia werc reparriated home. In all, Japan's relations with Asia concered a period of cotal halt.

Secondly, Ancrica laid the foundation for future negotiations between Japan and the Asian nations by incroducing the principle of war repararions. War reparations refer to the payments of reparation paid to the nations that have been victimized by Japanese imperialism. In other words, America assumed that prewar Japan had inflicted harm on to other nations by conducting the aggressive war and, consequently, the resolution of war issues was a prerequisite for the normalization of the relationships with those nations.

The issuce of war reparations was first raised during the war by the Allied Powers, which derined Japan as the aggressor. 23 The eleventh arricle of the Porsdam Dectaration stated that "Jilnan shail be permitted to maintain such industries as will sustain her economy and permit the exaction of just reparations in kind, but not those [induscries? which would enable her to re-arm for war. To this end, access to, as distinguished from contrel of, raw materials shall bx permitted. Eventual Japanese participation in world trake relations shall be permitted." During che early phase of the occupation, the American government adhered to this position and repeated it in the United States the initial post-surrender policy for Japan. 24 In other words, SCAP made it clear that Japan should bear economic burdens toward Asian nations that have been victimized by Japar's aggression. As a result, the payment of war reparations emerged as a key element in the settlement of war issues between Japan and the Asian nations.

In the early phast: of the occupacion, the Allied Powers maintained the principle of war reparations and pushed forward with reparation payments. I Iaving arrived in Japan on November 13, 1945, the Edwin Pauley Commission argued that Japan's industries were predominantly for military purposes and, despite the destruction during the war,

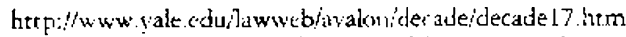

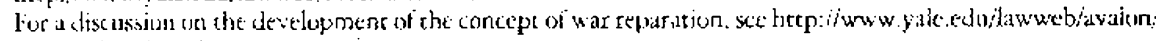
decieteridecaticlihem

"The original text is as tollows: "Reparacous for Japanese dggressum sliall bxe made: (a) throush the transter

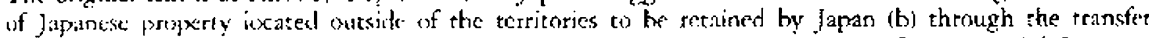
of such gouds to existing capital equipment and ficcilities as are not necessary for a peaceful Japranest

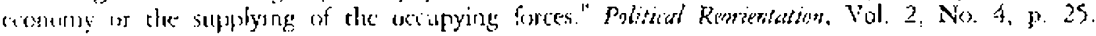


their induscrial capacities excected the demands of the peaceful economy. Thus, it advised chat the occupation authorities should transfer the surplus in Japan's industrial capacities to the invaded countries as a way of demilitarizing Japan. In line with that, in April 1947 , the Far Eastern Committee decided on the interim plan for reparation and issued a directive to MacArthur to send a portion of Japan's industrial facilities to the nacions that have been inflicted with damages by Japan's aggression. As a result, the four nations including China, the Netherlands (for Indonesia), the Philippines, and Britain (for Malaysia) have ecceived reparation paymonts that cams: to a total of approximately 165 million yen (Utsurni, 132-33).

However, America's reparation policy began to change in 1947. As the Cold War escalated, the focus of the occupation policy moved from democratization to stabilization. Thus, in December 1947, the Clifford Strike Commission, dispatched by America, reported that the industrial facilitics that could be effectively utilized within Japan should not be removed, with the exception of military facilities. Hurthermore, in March 1948, the William Draper Commission, dispatched by the Department of the Army, called for a fundamental review of reparations by reporting that the transfer of Japanese industrial facilities was harmful to the goal of the occupation. In Octoher 1948, the American government decided that the economic recovery would be the first priority of the occupation policy. In the end, the Allied Powers decided to suspend of the interim reparations that were already in progress on May 12, 1949) (Utsumi; Hara). In short. the escalation of the Cold War alanged America's occupation policy and resulted in the abandonment of the reparation policy.

The impact of the Cold War on America's policy of war reparation grew even clearer following the Korear War. Soon after the outbreak of the Korean War, the American government began to prepare for the peace treaty. In November 1950, America presented the principles for the peace treaty, which included the renunciation of the right to seek reparation by the Allicd Powers (Utsumi, 1.34). America's plan to exclude war reparations was met with strong objections by Asian mations, of which the Philippines voiced the strongest opposition. As a consequence, America had to concede and include in the peace treaty that Japan had the obligation to pay' reparations. However, at the same time, Article 14 allowed Japan to avoid or delay the payments, saying that "the resuurces of Japan are not presently sufficient, if it is to maintain a viable economy, to make complete reparation for all such damages and sufferings, and at the same time, meet its other obligations."

Ta) recapitulate, America's view of the war and its policy on war reparations laid the groundwork for Japan's postwar relationships with Asian nations. America defined their relationship to be that of the aggressor and the sictim. As a result, Japan was held responsible for paying war re'parations to Asian nations. However, America's condemnation of Japar's aggression underwent critical changes due to the Cold W $\mathrm{W}$ and was compromised in favor of Japan's interests. By the rime Japan signed the peace treaty, it was endowed with room to shape the issue as to its own will. In contrast, the claims macte by Asian nations were not sufficiently teflected in the peace creaty as showcascd by the exclusion of Koreia and China from the signing of it. 
During the oxcupation, the initiative of the reparation issue was in the hands of the American government. Ilowever, it does not mean that the Japanese government did not have any influence over the issue. Unlike the case of Germany, the Allied Powers decided to leave the existing government in place and operate through it in order to rule Japan. The indirect-rule arrangement opened the way to much more Japanese inflience in shaping occuparion measures than had originally been expected (Passin 1970, 109). Thus, as for the development of the issue of wat reparations, the Japanese government exerted influence, although in a limited way.

Then, what was the position of the Japanese government over the issue of war reparations? Japan's approach to this issue was different from that of America's. America's reparation policy was based on the view that Japan had inflicted great harm to the Asian nations through expansionist policies. However, as seen before, the Japanese government did not fully accept that view. In particular, the Japanese government tended to deny its responsibilicy about its actions prior to the war with America. As for its invasion of China since the Manchurian lucident of 1931 , it continued to define it as an incident (jiben), not as a wat (cinso). In a document prepared in 1949, for instance, the foreign ministry argued that it would not accept the view that defines the Manchurian Incident and the Chira Affair as wars. Thus, it insisted that the future peace treaty not be applied to the relationship becween Japan and China (Tanaka 1993, 55).

A similat position is tound in its relation to Korea. It is truc that the case of Korea is different from that of China in that Japan had already colonized it. However, by the very fact of colonization, the issue of the past presented a much more serious problem in Japan's relationship with Korea. The Japanese government's position over the negotiation with Korea can be found in a couple of government documents. In 1950, the Finance Ministry published the results of a survey on Japanese-owned properties in its former colonies, including Korea. The goal of the survey was to provide legitimacy to the claims for Japanest-owned properties in former colonies (Takasaki 1990, 225). In line with rhat goal, orse of the articks in the volumes challenged basic assumptions about Japanese rule in Korea. First, it denied the view that Japan's colonial rule in Korea had enslaved and expropriated Koreans in a way much worse than the Westerners had done. Second, it argued that Korea had achieved a great deal of development during the last thirty years, thanks to Japan's leadership. In other words, the author of the artick denied the vice: that Japan should be held responsible for the colonial rule of Korea. Nlmost the same view is found in another government document prepared in 1949 by the Ministry of Foreign Affairs, which also denied Japan's exploitation of Korea and insisted on Japan's contribution to Korea's modernization instead (Takasaki 1990, 225-27).

In short, two important, but contradicting, elements were shaped during the occupation period. First of all, the principle of war reparations was established as the basic solution to the issue of the past. Secondly, the Japanese government tended to minimize its war responsibilities. The inherent contradiction of the two clenents did not surface during this period. However, once Japan regained independence, it served as a kcy problem in the normalization of Japan's relations with Asian nations. 


\section{The Post-Independence Era (1952-1965)}

Japan signed the San Francisco Peace Treaty in 1951. The signing of the peace treaty opened the door for Japaris re-entry into the international work. Now, Japan formally regained the rights to conduct diplomatic affairs on its own. After the independence, thus, Japan sought to restore its international position diplomatically. As a tesult, beginning w'ith its admission to the Unired Nations in 1956, Japan became an increasingly active member in international politics, as well as economic and social forums. The securicy arrangements with the Inited States, originally signed in 1951, were revised in 19 (0) with a view to make them more reciprocal. In the process, the re-establishment of diplomatic relationships with Asian nations was pursued with increasing emphasis.

As cxamined earliet, the settement of war issues became the key factor in negotiations. The San francisco Pcace Treaty obliged Japan to pay war reparations to the nations that had been inflicted with harm during the war. However, the process of nommalizing political and economic relations was not simple, for Japan had to overcome the resentment of the Asians caused by the war. Although Japan accepted the condition of paying reparations, these wid a huge gap in the assessment of the amount of payments between Japan and the Asian narions. The difference was not only about the amount of payments. More important was the difference over the narure and degree of harm that Japan had supposcedy inflicted upon those nations. Throughout the negotiarious, the Japanese government showed exteme care in not openly recognizing its war tesponsibilities. In the end, negotiations rended to proceed from economic siewpoints, while the issue of Japan's war responsibilities was not dealt with sufficiently.

Japan's efforts to rebuild formal relacionships with Asia began soon after the independence. The first occasion was the formalization of its relationship with Taiwan. Because China was a main battlefield during the war, it was inflicted with the greatest harm. Consequently, the scttement of war issues occupied the cencral pesition in restoring formal relations with China. However, the establishment of the Communist regime in the continent and the rerreat of the Nationalist government into Taiwan created a diphomatic problem for the Japanese government. While Japan was intent on resuming its relations with the Communists in China, America urged Japan to side with Tawan. In the end, Japan succumbed to America's demands and signed the peace treaty with Taiwan in April 1952. Orte of the most distinctive aspects of the treaty was Taiwan's renunciation of the right to war reparations. Although Taiwan called for reparation payments for the damages done wo China, its claim was regarded groundless by the Japanese government, which argued chat Taiwan did not have the jurisdiction over mainland China. In the end, Taiwan renounced its right to war reparations. Considering that the treaty aith Japan was a welcome telief tor laiwan from international isolation, it was nut difficuls to understand why the issue of war reparations was sidetracked in the process (Ianaka 1993, 57). Japan succeeded in concluding the ereacy with Taiwan without ejther reparation payments, or the formal recognirion of war responsibilities.

In the meantime, despite its relationship with Tawan, Japan continued to pursue intcrourse with China during the 1950s. In pirticular, a considerable number of Japanese 
people regarded China as an important partner not only in trade, bue also in regional strategy (Iriye, 99-101). However, within the strategic continement of the Cold War, it soon became clear that Japan's interests lay with Taiwan, not with China. The result was the policy of the Kishi cabinet, which pursued an Asian policy oriented toward the Southeast, while giving up the normalization of its relationship with China.?5 Consequently, the fact that the Nagasaki Flag lncident tesulted in the rapid deteriotation of Japan's relationship with China was not an accident.

The real ecst for the normalization of Japan's relationships began as the negotiations with the Southeast Asian nations took place. While most of the participants in the peace treaty renounced the right to reparations, six parcicipants from Southeast Asia did not. Antong them, Cambodia and Laos waived the right in 1954 and 1956, respecrively. However, other natious actively sought the reparations and Japati's negotiations with these nations lexian swon after the signing of the peace treaty. In December 1951, for instance, negotiations with lndoncsia began as it dispatched a delegation to Tokyo. Negotiarions with the Philippines began in January 1952. As a tesult, reparation agreements were signed with Burma (1954), the Philippines (1956), Indonesia (1958), and South Vienam (1959). However, the agreements were not made easily. Except in the case of Burma, the uegotiations sere stalled over the amount of reparation payments. ${ }^{20}$ For instance, the first meteing with Indoncsia ended without an agreement when Indonesia demanded seven billion dollars. The mecting with the Philippines met a similat fate, as the Philippines demanded eighe biltion dotlars. Japan suggested the payment of the total of 135 million dollars to the Philippines, Indonesia, and Burma in late 1953. Conseguently, negotiarions were stalled over the amount of reparations. Another problem was that the Japinese government was not eager in pursuing the normalization of its relations with those nations. It was only when the Kishi government (1957-1960) sought to enhance econonic developmene by building an econonic network with the non-Communist Asia. that the negotiations were rcinvigonated (Miyachi, 3483). In the end, final agrecrients were made in the lateer half of the 1950) and Jajan was successfully reinegrated into Southeast Asia. However, the final sum of the payments was a portion of what those nations had demanded. ${ }^{27}$ In short, economic consideracions played a critical role in Japaris approach $\varepsilon$ o the relacions with Southeast Asia.

Entering the 1960s, Japan resolved most of the outstanding diplomatic issues in Asia, except the cases of Korca and China. Considerity that its rclationship with China was defined by the Cold War, it is possithle to say that its retation with Korea was the only remaining problem. The Japanese governmenr tegan ralks for the normalizarion of the relationship with the Korean government. The first talk was held on February 15, 1952, following the preparatory talk held in Novernber 1951. With that as the

\footnotetext{
Fin example, Kishi macte in ofticiul visit tis Tilwan in 195 ?

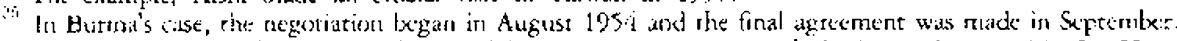

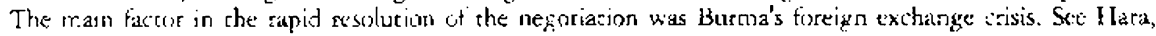
pp. $2: 78$

For instance forknesial rectived 223.3 million doilars and the Philippines, 550 million dollars. The rotal repatrutuons to the four nations ilndensesia, the Philippines, Burma, and Sout in Vietnam) was a little over

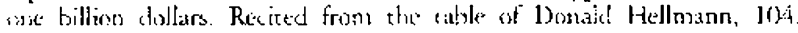


beginning, the calks between two nations cuntinued intermittently until the final agreement in the seventh meering of 1965 (Lee: Takasaki 1996).

One of the most critical factors in prolonging the negotiations was the gap in the views of Japan's colonial rulc in Korea and the amount of reparations to be made to Korea. From the beginning, the Korean government made financial compensations for colonial rule as the key item in the negotiation. However, the position of the Japanese gevernment was quite contrary. First, it did sot accept the view that Japaris colonial rule had been harnful and repressive. The contradiction in the views of the past was evident from the beginning. According to a testimony by Korean participants. Chiba Hiroshi, one of Japan's representatives for preparatory calks, refused to accept the fact that Japan had invaded Korea against the will of the Koreans (Takasaki 1996, 24). In line with that, Japan demanded compensation for Japanese ptoperties in Korea in the first official negotiation held in 1952 (Lee, 51-58). From that proint on, Japan's claim to Japanese-owned properties in Korea became the focus of the dispute.

In this respect, the so-called, "Kuboda statement of 1953" was not an accident. His statement contained following claims. First, Japan's colonial rule had beneficial results to the Koreans. Second, the description of the Cairo Declaration of Koreans as being in a scate of slavery was a result of war hysteria. Third, the confiscacion of Japanese properties in Korea by a directive of the occupation authority was a violation of internacional law. Fourth, the indepenkdence of Kurea priur to the signing of the peace treaty was a violation of international law. Finally, the forceful repatriation of Japanesc nationals from Korea was a violation of international law (Lee, 66). With this incident as a turning point, the negotiation broke down and was not resumed until 1958.

In the meantime, the resumption of the negotiations did not come from the resolution of the contesution over the past. It was rather by the change in the policy of the Kishi government, which sought to establish Japan's conomic influence over Asia, induding Korea. In line with that, the Ikeda government decided the policy of approaching the negotiation in the form of economic development grants and finally reached an agreement with Korea. As a result, Korea came to receive 300 million dollars between 1966 and 1975. However, it is important to note that Japan's payments were made in the name of economic development grants. The Japanese government had intended to eliminace the implication of compensation from the payments for the past (lee. 209). Furthermore, the official treaty dicl aor include Japans manifest apologies over the past. It only hinted at the existemes of the problem of the past in the opening phrase, which mentioned "the historical background of relationships between their prople and their mutual desire for good neighborliness" as one of the grounds for the treacy.

Ti recapitulate, Japan achieved the goal of normalizing its relations with Asian nations by 1965 , except the ones in the Commutist camp. However, it was far from the fact that the nomalization meant the fult settlement of war issues. On the contrary, the process of the talks between Japan and its counterparts revealed the gap in the views of the past and, instead of resolving it, ended up equivocating on the issuc. 


\section{CONCLUSION}

Postwar Japan has achieved a remarkatsle economic growth and became a leading country in Asia. However, there are many uncertainties in its future status and role in Asia. Among the reasons for such uncertainties lies the so-called, "the issue of the past," which refers to the history of Japanese imperialism in Asia. As the dispute over history slows, there are serious doubts about Japan's position both in and out of Japan and such doubts remain a critical obstacle in defining Japan's international tole.

In this scudy, I examined how postwar Japan's view of the past was shaped and how ic influenced Japaris relations with Asian nations as a way of explaining the present dispute and its international ramifications. As a result, I showed that the basic struccure of postwar Japan's view of the past was shaped during the first two decades after the defear. Also, despite the apparent success in normalizing relations with Asian nations, Japan failed to fully resolve the issue of the past and its view of it played a big role in the process.

There are many indications that Japan's view of the past is improving. Entering the 1990s, many in Japan began to raise the issute of war responsibilities and are looking for ways to resolve the remaining issues (Isbida). However, their attempts met serious challenges from the conservatives, who tejected the calls for war tesponsibilities and emphasized the sanctity of national memories (Matsubimu E Shiromaru). In line with that. Japan's commemoration of the fiftieth year after the defeat in 1995 demands attention. The commemoration received special atention both within and atroad not only because half a century was passed from the point of the incident, but also because there were several renarkable developments. First, Japan was undergoing a political upheaval as the monopoly of the Liberal Demoratic Pasty collapsed and a socialist occupied the sear of Prime Minister. Also remarkable was the growth of public awareness surrounding the war issues in the form of cliscourses on responsibilities (Senso Sekininron). In particular, Japan's parliamenc decided to make an official resolution over the issue. At the same time, however, upprasites voices grew rapidly. Conservative politicians strongly rejecred the government's attempt for a resolution. In the end, as a result of compromise, the resulution stopped at mentioning Japan's war responsibilities in a vague manner (Waila). In short, the commenoration resulted in revealing Japan's inability to deal with issucs of the past.

Then, what do the recent developments hold for Japan's relations with Asian rations? I believe chat recent developments in Japan slow that the basic structure of postwat Japan's view, which was formed in the beginning of the prostwar era, remains with little change, as it continues to be a key factor in Japan's reluctance in dealing with the issue of the past. Some argue thar the passage of half a cencury should relieve Japan of its burdens from the past and that Japan and other Asian nations should look for the fucure. However, as the sheer incensity of the dispute over history within the Japanese society shows, the past will nor go away easily. Conseçuently, the issue of the past will continue to overshadow Japan's relations with Asian nations in the fucure. 


\section{REFERENCES}

Akira, Hara. 1993. "Senso Baisho Mondai To Ajia" ["The Issue of War Repatation and Asia"]. In Kuanami Koza Kinclai Nibon Th Shokuminchi [Wwanami History of Modem Japan and Colonies] Vol. 8. Iwanami Shoten.

Dirlik, Arif, 1993. "Past Experience, If Not Forgotten, Is a Guide to the Future"; Or, What is in a Text? The Policics of History in Clinese-Japanese Relations." In Japan in the Worle, eds. Masao Miyosi and H.D.Harootunian. N.C.: Duke University Press.

Eiichi, Matsushima. and Fumio Shiromaru. 1997. Jiyushagi Shikan No Byari [The Patbology of the Jiyushugi Shikan Grozip \} Ogetsu Shoten.

Fusan, Hayashi. 1964. Daitiasenso Koteinn [The Affimation of the Greater Fast Asia Wara]. Banchos shobo,

1965. Zaku Dutoasenso Kiteiron [The Affimation of the Greatie East Asia War]. ?nd Vol. Bancho Shobos.

Gaimusho,ed. 1965. Nibn gaiks nenpy narahi jury monjo [Chronology and Documents of Japnese Diphnacy]. Vol. 2. Hara Shobo.

Gluck, Carol. 1992. "The Idea of Showa." In Showa: The Japan of Hirbito, eds. Gluck, Carol and Stephen R. Graubard. W.W. Norton \& Company.

Hanc. Mikiso. 1986.Mndem Japan: A Historiat Sumey. Westview Press.

Haruki, Wada and 1shizaka Koji. 1996. Nibon Wa Shokminsi Sibai Wo Do Kangate Kitakia [How fapan Has Vieut Its Colmital Rule?], eds. Sngo Gojunen Kokkai Kersugi Wo Motomeru Kail. Nashi No Ki Sha.

Hellmann, Donald. 1972. Japan and East Aiza. Praeger Publishers.

Hiroshi, Tanaka. 1993. "Nihon No Sengo Sekinin To Ajia" ["]apan'S Postwar Responsibilities and Asia"]. In Lwtrami Koza Kindai Nibon To Shokuminibi [Hanami History Of Mndem Japun ind Coflontis]. Vol. 8. Iwanami Shoecn.

Junichiro, Kisaka, 1995. "Ajia Taiheiyo Senso No Rekishiteki Seikaku To Megutte" ["On The Historical Nature of the Asia-Pacific War"l. In Nenpo Nibun Gendaishi Uoumal of Contempurary History of Japan]. No. 1.

Katsutoshi, Namimoto. 1977. "Kyokasho Kentei Sosho" ["The Trial on the Textbook Authorization"]. In lwanami Koua Nibon Rekesbi [Wwanami History Of Jatan], No. 24. Iwananis Shoten.

Katzenstein, Peter J. 1997. "Asian regionalism." ln Netuort Potver: Japan and Asia, eds. Katzenstein, Peret J. and Takasti Shiratshi. New York: Cornell Liniversity Press.

Keji. Nagahara. 197? "Sengo Nithon Shigaku No Tenkai To Shochoryu" "The Development And Currents in Postwar Japan'S Historical Studies"]. In Iwartami Koza Nibon Rekisb: [Iuanami Hestory of Japan]. No. 24. Iwanami Shoren.

Kenkyukai, Rekishi.ed. 1995. Sengo Gojymen Wo Do Miruka [How to View the Fifty Years afler the War]. Aoki Shocen.

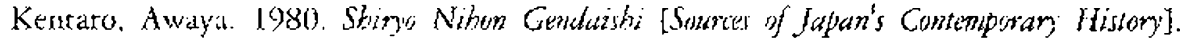
Vol. 2. Daigetsu Shotcin.

Kiyosha, Inoue. 1959. "Sengo Rekishigaku No Hansei To Tomen No Kadai" ["Development of Historical Studies in the Postwar Period : An Examination and Prospect"]. In Rekisbigaku 


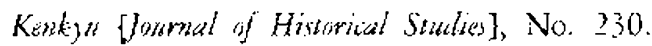

Kotenori, Yokoyama. 1998. "Kyokasho Saitan To Gikushu Shito Yoryou" ["The Textbook Trial and the Essentjals in Teaching Guidelines"]. In Rekisi No Hotet the Coun of Histurt]. Ogetsu Shoten.

Koschmann, J. Vicror. 199?. "Asianism's Ambivalent legacy." In Netuprk Pouer: Japan and A.ia, eds. Katzenstein, Peter J. and 'lakashi Shiraishi. New York: Cornell Universicy Press.

Miner, Richard 1971. Viateg's Jhitice: The Tukgn War Crimes Trial. New Jerscy: Princeton Universicy Press.

Passin, Herbett. 1992. "The OccupationSome Retlections." In Sbmua: The Japan of Hirobitu, eds. Gluck, Carol and Stephen R Granbard. W.W'. Norton \& Company.

Pilitial Remintatus of Japan. Suptember 1945 to September 1948, 1970. Vol. 2. Greenwood Press.

Saburo, lenaga. 1963. "Scrgon No Rekishi Kyorku" ["Postwar Japan's History Education";.

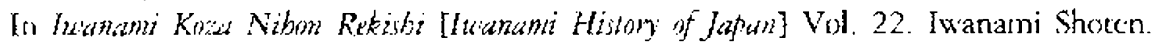
Shigeki, Toyama, 1968. Sensu No Rekishiguku Tio Rekisbi ljbiki [Postuar Japan'S Historial Studier Aud The Historical Conscionsnesj]. Iwanami Shoten.

Shigeki, Toyama and lenaga Saburo, et.al. 1967. Kigensetsu Mondati [The Issue of she National Fonmkation Day]. Aoki Shoten.

Shirsichi, Arai. ity5. "Scrigo Gojunen To Scnso Sekinin" [Fifty Years after the War

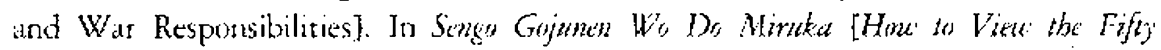
Yuars affer the War\}, ed. Kenkyukai, Rekishigaku. Aoki Shoten.

Shiro, Akasawa 19?6. "Shocho Temnosei No Keisei To Scnso Sekininron" ["Formation of the Symbolic Emperor System and the Issue of War Rcsponsibilitics"]. In Rekishi by'm ['The Hirforical Revitic] (July).

Takcshi, Ishida. 19\%6. "Senso Sekininron Saito" ["A Reconsideradion of the lssue of War

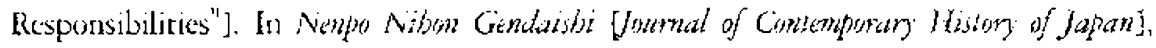
Ni) ?.

Tokushiro, Hattori. 1965. Datua Senso Zenshi [The History of the Greater Fast Aria War]. Hara Shubo.

Whicing, Allen S. 1989. China Eyes Jatan. Calif: University of California Press.

Yoshio, Asai. 1993. "Sentyo Seisaku No Denkan To 'Kyaku Ko-Su" ["Changes in the Occupation Policies and the Reversc Course"]. In Senno To Sengo Katkaku [The Owapatom whut the Postuar Reformy. Yoshikawa Kobunkan.

Yoshibumi, Wakaniya. 1995. Sengi Inobu No dijakan [Pastuar Japan's Consematites and that Vicie Asial. Asahi Slrinbunsha.

Yoshida, Yudaka. 1995. Nibinjin Ni Sensokun [The Japanee Vien of the War]. Iwanami Shoten.

Yui, Masatomi. 1994. "Scnryoki Ni Okeru "1aiheiyo Senso'Kan No Keisei" ["The Formation of the Narrative ot the Pacific War During the Occupation Period"t. In Shikan [Hasturial Perspetize]. No. 130 (March). 